\title{
Incomplete Contracts and Ownership: Some New Thoughts
}

\section{Citation}

Hart, Oliver, and John Moore. 2007. "Incomplete Contracts and Ownership: Some New

Thoughts." American Economic Review97 (2): 182-86. https://doi.org/10.1257/aer.97.2.182.

\section{Permanent link}

http://nrs.harvard.edu/urn-3:HUL.InstRepos:41534601

\section{Terms of Use}

This article was downloaded from Harvard University's DASH repository, and is made available under the terms and conditions applicable to Other Posted Material, as set forth at http:// nrs.harvard.edu/urn-3:HUL.InstRepos:dash.current.terms-of-use\#LAA

\section{Share Your Story}

The Harvard community has made this article openly available.

Please share how this access benefits you. Submit a story.

\section{Accessibility}




\title{
Incomplete Contracts and Ownership: Some New Thoughts
}

\author{
By Oliver Hart and John MoOre*
}

Since Ronald H. Coase's famous 1937 article, economists have grappled with the question of what characterizes a firm and what determines its boundaries. ${ }^{1}$ Transaction cost economics (see, e.g., Oliver Williamson 1975, 1985; Benjamin Klein, Robert G. Crawford, and Armen A. Alchian 1978) argues that firms are important when contracts are incomplete, and parties make large relationship-specific investments. Property rights theory (see, e.g., Sanford J. Grossman and Oliver D. Hart 1986; Hart and John Moore 1990) refines this thinking by taking the view that the owner of a nonhuman asset possesses residual control rights over that asset, and that there is an optimal allocation of such residual control rights. As a consequence, not all activities should take place in a single firm.

The modeling approach used in most of the incomplete contracting and property rights literature is one in which renegotiation of an incomplete contract always leads to ex post efficiency, and the focus is on distortions in ex ante investments. In this paper, we argue that such an approach is restrictive. We suggest, in future work, it may be useful to broaden the approach to include some new elements, such as behavioral ones. This will help to generate a theory of ex post inefficiency. We describe a first attempt along these lines based on Hart and Moore (2006).

\section{A Simple Version of Property Rights Theory}

Consider a buyer $B$ who requires a service from a seller $S$ in the future at date 1 . The nature of this service will be known at date 1 when the parties trade, but is uncertain at date 0 when they first meet and contract. Between dates 0

* Hart: Department of Economics, Harvard University, Littauer Center 220, Cambridge, MA 02138 (e-mail: ohart@ harvard.edu); Moore: Department of Economics,Edinburgh University, 336 William Robertson Building, Edinburgh, Scotland, EH8 9JY, United Kingdom (e-mail: j.h.moore@ ed.ac.uk). The authors are grateful to Luigi Zingales for helpful comments.

${ }^{1}$ For a recent survey see Robert Gibbons (2005). and 1, $B$ makes a noncontractible relationshipspecific investment that increases his value from receiving the service. The cost of the service is unaffected by this investment and is taken to be a constant. $B$ 's value exceeds $S$ 's cost, so there are always gains from trade. An optimal contract ensures that these gains from trade are realized and that $B$ invests efficiently.

First, consider what happens if the parties postpone contracting until date 1 when $B$ 's investment is sunk. Suppose symmetric information about value and cost at this stage. According to standard thinking, the parties will realize the ex post gains from trade through bargaining and will split the ex post surplus in some way, e.g., 50-50. A 50-50 split, however, implies that $B$ receives only half of an increase in the value of the service caused by his noncontractible investment. Anticipating this, $B$ underinvests. This is the well-known hold-up problem. ${ }^{2}$

One solution to the hold-up problem is for $B$ and $S$ to write a contract at date 0 that fixes the date 1 terms of trade before $B$ invests. This may be problematic given that the nature of $S$ 's service is uncertain at date 0 . Property rights theory explores a second solution, which is to allocate ownership of the assets $S$ works with (e.g., a plant or factory) to $B$. Even in the absence of a long-term contract, this strengthens $B$ 's bargaining position at date 1 since $B$ always has the option to replace $S$ with someone else who can operate the assets. Given this, $B$ will now receive a greater fraction of the ex post surplus, which will strengthen his investment incentives. This is the simplest example of how allocating asset ownership can reduce underinvestment and increase efficiency.

This model, as it stands, has some weaknesses. First, the parties may be able to devise a clever mechanism that overcomes the fact that the nature of trade is uncertain as of date 0 . Two such mechanisms have been proposed. In one, the parties try to allocate date 1 bargaining power. In the model described above, since

\footnotetext{
${ }^{2}$ For a formalization see Paul Grout (1984).
} 
$B$ is the only investing party, it is desirable to allocate $B$ all the ex post bargaining power. One way to do this is for the parties to agree at date 0 that $B$ has the right to make a take-it-or-leave-it offer to $S$ at date 1 . $B$ will propose the efficient service for a price just above $S$ 's cost and will receive all the surplus. One potential problem with such a scheme is that $S$ might reject $B$ 's offer and try to renegotiate a better deal. If there is a deadline for trade, however, $B$ can ignore such a rejection, confident that at the last moment $S$ will accept $B$ 's offer, since a small profit is better than nothing. ${ }^{3}$

A second mechanism is based on the ideas of Eric Maskin (1999), Moore and Rafael Repullo (1988), and Maskin and Jean Tirole (1999). These authors have argued that in a world of symmetric information there are ingenious ways of making this information verifiable, i.e., available to outsiders such as the courts. Enforceable contracts can therefore be made contingent on this information. In the model above, the parties could, for example, agree as part of the date 0 contract that $B$ can choose any service he wants at date 1 , but must pay $S$ her cost. $S$ will announce her cost (which, recall, $B$ observes). If he chooses, $B$ can challenge $S$ 's announcement. In this event $S$ pays a large fine to a third party. $B$ 's challenge is then "tested" by seeing whether $S$ supplies the service at a price slightly below $S$ 's announced cost. If she does, i.e., $B$ 's challenge is "validated," the third party transfers $S$ 's fine to $B$. If not, i.e., $B$ 's challenge is "invalidated," $B$ also pays a large fine to the third party. It is not difficult to show that the unique subgame perfect equilibrium of this game has $S$ reporting her cost truthfully, i.e., $B$ receives all the ex post surplus. ${ }^{4}$

These mechanisms, particularly the second, are troubling. If the model described reality accurately, one would expect to see such mechanisms being used at least sometimes. The fact that they aren't used suggests that the model may be missing something important.

The model can be criticized on other grounds. The reliance on noncontractible, relationship-

\footnotetext{
${ }^{3}$ See Joel Watson (2007) for a recent analysis along these lines.

4 A very recent paper by Philippe Aghion, Drew Fudenberg, and Richard Holden (2006) suggests that this mechanism may not be robust to small amounts of private information.
}

specific investments is somewhat unsatisfactory because, almost by definition, such investments are hard to measure empirically. ${ }^{5}$ Also, the assumption that parties always bargain to an ex post efficient outcome using side payments seems a poor description of what goes on inside the firm.

All of this suggests that it is worth trying to develop alternative models.

\section{An Alternative Model of Ownership}

Hart and Moore (2006) develop a theory of (incomplete) contracts based on the idea that a contract is a reference point for parties' feelings of entitlement, and that feelings of entitlement affect contractual performance. The basic elements of the theory are as follows. Consider a situation similar to that above but without noncontractible investments-a buyer $B$ wants a good or service from a seller $S$ at date 1 . To simplify matters, suppose that the good is homogeneous - a widget. Between dates 0 and 1, a "fundamental transformation" occurs in the sense of Williamson (1985); there is perfect competition at date 0 but bilateral monopoly at date 1 . This transformation may be the result of relationship-specific investments, but, if so, they are not modeled.

When the parties meet at date 0 , they are uncertain about the state of the world. This uncertainty will be resolved shortly before date 1 . There is symmetric information throughout, but the state is not verifiable. A date 0 contract can be thought of as specifying a set of possible outcomes from $B$ and $S$ 's date 1 transaction, where an outcome is a price-quantity pair. (The outcomes cannot be state contingent because the state is nonverifiable.) The contract may also provide a mechanism for choosing from this set.

Hart and Moore make the assumption that the date 0 contract serves as a reference point for the parties' sense of entitlements at date 1 . Specifically, neither party feels entitled to an outcome outside those permitted by the contract. Implicitly the contract is regarded as "fair" by both parties because it was negotiated under competitive conditions at date 0 .

\footnotetext{
${ }^{5}$ See Michael Whinston (2003) for a discussion.
} 
Within the contract there can be disagreement about the appropriate outcome, however. To simplify matters, it is supposed that each party feels entitled to the best possible outcome permitted by the contract. Of course, this means that typically at least one party, and possibly both, will be disappointed or aggrieved by the outcome.

What are the consequences of aggrievement? Hart and Moore make a second assumption that the outcome from the transaction is not perfectly contractible even at date 1 . In particular, assume that each party has the discretion to provide "perfunctory" performance rather than "consummate" performance. We refer to such behavior as shading and suppose that it cannot be observed or penalized by an outsider (e.g., a court). (A court can, however, enforce perfunctory performance.) Consummate performance does not cost significantly more than perfunctory performance (it may even be pleasurable), and a party will provide it if he feels well treated. He will shade if he is aggrieved ("negative reciprocity"). Shading hurts the other party and causes a deadweight loss.

To be more precise, Hart and Moore assume that, if the outcome chosen from the contract causes $S$ to feel aggrieved by $\$ k$, i.e., $S$ 's payoff is $\$ k$ less than under the best possible outcome, then $S$ shades on her performance so that $B$ 's payoff falls by $\theta k$. Here, $\theta$ is an exogenous parameter, $0<\theta \leq 1$. The situation is similar for $B$. Note that we assume symmetry. $B$ and $S$ can both shade and they face the same parameter $\theta$. A final assumption is that parties cannot shade if they do not trade. Note that shading costs can be thought of as also capturing other kinds of transaction costs such as haggling, rentseeking, and influence costs.

To see the implications of the assumptions above, let $B$ 's value from the widget at date 1 be $v$. Assume that this widget is costless for $S$ to produce, but that it has an opportunity cost $r$. Trade is efficient if and only if $v \geq r$. As of date $0, v$ and $r$ are random variables with a probability distribution that is common knowledge. (Recall that there are no ex ante investments.) Make the additional assumption that, if trade does not occur at date 1 , the responsible party cannot be ascertained. Thus ex post trade is voluntary. Under these conditions, Hart and Moore show that only the difference between the trade price and the no-trade price matters, and that one can normalize the no-trade price to be zero. Note that lump-sum transfers can be used to redistribute surplus at date 0 .

Start with the case where there is no uncertainty: $v, r$ are constants and $v>r$. Then the following contract achieves the first-best outcome. The parties agree, at date 0 , that $S$ will supply the widget to $B$ at date 1 for a given price $p$, where $r<p<v$. Such a contract ensures trade and causes no aggrievement because each party obtains the best outcome permitted by the contract (the contract specifies only one outcome, trade at price $p$ !).

Note that even in this simple situation there are many contracts that are not optimal. For example, consider a contract that says that the price can be anything in the $[r, v]$ range, and that $B$ will choose the price. Then $B$ will choose the lowest price $p=r$ at date 1 . However, $S$ will be aggrieved that the best outcome for her, $p=v$, wasn't chosen and she will shade, causing a deadweight loss of $\theta(v-r)$.

Matters become more interesting if $v, r$ are uncertain. Now a contract that specifies a single trading price $p$ will lead to trade if and only if $v$ $\geq p \geq r$, i.e., both parties gain from trade. The difficulty is that, if $v, r$ are stochastic, it may be impossible to find a single price $p$ that lies between $r$ and $v$ whenever $v>r$.

Under these conditions, a contract that specifies a range of trading prices $[\underline{p}, \bar{p}]$ may be superior. (Hart and Moore show that one does not need to go beyond a contract that specifies a no-trade price of zero, a range of trading prices $[\underline{p}, \bar{p}]$, and has $B$ choose the price.) The larger the range $[p, \bar{p}]$, the more likely it is that $B$ can find a price between $r$ and $v$ whenever $v>r$. This is the benefit of a large range $[p, \bar{p}]$. There is a cost of a large range, however; typically there will be many feasible prices between $r$ and $v$ when $v>r . B$ will pick the lowest price but $S$ will feel aggrieved that $B$ didn't pick the highest and will shade, causing a deadweight loss. The optimal contract trades off these effects.

There is one important issue that we have ignored. If $v>r$, but there is no price in the range $[\underline{p}, \bar{p}]$ such that $v \geq p \geq r$, one might expect the parties to renegotiate their contract. Renegotiation does not change the analysis fundamentally, and so, for simplicity, we rule it out (see Hart and Moore 2006 for a discussion). 
We now turn to the issue of ownership. So far, we have implicitly supposed that $B$ and $S$ are separate entities ("nonintegration"). Assume now that $B$ acquires $S$ 's operations (assets) at date 0 ("integration"). We will take this to mean that $B$ can get someone else to produce the widget (costlessly) at date 1 . In effect, $B$ now owns and possesses the widget. We suppose that $S$ 's human capital is still required to realize the opportunity cost $r$. That is, to earn $r, B$ must sell the widget back to $S$. Thus the model is the same as before except that the status-quo point at date 1 is reversed. If no trade occurs, $B$ earns $v$ (since $B$ "owns" the widget), while if trade occurs, $S$ earns $r$ and pays $p$. Trade is now efficient if and only if $r \geq v$ (it is still voluntary). A contract consists of a no-trade price of zero and a range of trading prices $[p, \bar{p}]$, with $S$ choosing the price. $S$ will choose the smallest price such that $r \geq p$ $\geq v$, whenever $r>v$.

As we do not have the space to conduct a complete analysis of the differences between nonintegration and integration, we confine ourselves to the following observations. Suppose $v$ $>r$ with probability 1 . Then, as we have seen, under nonintegration, it may be impossible to achieve the first-best. The reason is that in order to ensure trade with probability 1 , it may be necessary to have a range of trading prices, but this leads to aggrievement and shading whenever there is more than one price such that $v \geq p \geq$ $r$. In contrast, integration achieves the first-best because the status-quo point is such that $B$ possesses the widget, which is the efficient outcome. $S$ is irrelevant and does not (cannot) shade.

Of course, if $v<r$ with probability 1 , the situation is reversed. Now integration leads to inefficiency because a range of prices is required to ensure that $B$ always trades the widget to $\mathrm{S}$. This leads to aggrievement and shading whenever there is more than one feasible price in the range; while under nonintegration, the status quo point, in which $S$ possesses the widget, yields the efficient outcome without shading.

The reader will have noticed, that if $v>r$ with probability 1 (respectively, $v<r$ with probability 1), specific performance is an alternative to integration (respectively, nonintegration) as a way of achieving the first-best outcome. Specific performance requires an outsider (a court) to be able to verify who was responsible for the absence of trade, something we have not permitted. Even if we did allow this, however, specific performance is no longer a panacea if $v$ $<r$ with positive probability (respectively, $v>$ $r$ with positive probability), and it can be shown that there is still a role for integration (respectively, nonintegration). We leave the details to future work.

We conclude with an observation. As Dennis W. Carlton (1979) notes, business people often take the view that integration is useful for assuring input supply in an uncertain world. Our simple model captures this. When $v>r$ but $v, r$ are stochastic, nonintegration is typically inefficient-either trade will not occur when it should or there will be shading — while integration yields the first-best outcome. Note that the idea that integration assures supply has been hard to capture using existing approaches (see Patrick Bolton and Michael D. Whinston 1993).

\section{REFERENCES}

Aghion, Philippe, Drew Fudenberg, and Richard Holden. 2006. "Subgame Perfect Implementation with Almost Perfect Information." Unpublished.

Bolton, Patrick, and Michael D. Whinston. 1993. "Incomplete Contracts, Vertical Integration, and Supply Assurance." Review of Economic Studies, 60(1): 121-48.

Carlton, Dennis W. 1979. "Vertical Integration in Competitive Markets under Uncertainty." Journal of Industrial Economics, 27(3): 189-209.

Coase, Ronald H. 1937. "The Nature of the Firm." Economica, 4(16): 386-405.

Gibbons, Robert. 2005. "Four Formal(izable) Theories of the Firm?" Journal of Economic Behavior and Organization, 58(2): 200-45.

Grossman, Sanford J., and Oliver D. Hart. 1986. "The Costs and Benefits of Ownership: A Theory of Vertical and Lateral Integration." Journal of Political Economy, 94(4): 691-719.

Grout, Paul A. 1984. "Investment and Wages in the Absence of Binding Contracts: A Nash Bargaining Approach." Econometrica, 52(2): 449-60.

Hart, Oliver, and John Moore. 1990. "Property Rights and the Nature of the Firm." Journal of Political Economy, 98(6): 1119-58. 
Hart, Oliver, and John Moore. Forthcoming. "Contracts as Reference Points." Quarterly Journal of Economics.

Klein, Benjamin, Robert G. Crawford, and Armen A. Alchian. 1978. "Vertical Integration, Appropriable Rents, and the Competitive Contracting Process." Journal of Law and Economics, 21(2): 297-326.

Maskin, Eric. 1999. "Nash Equilibrium and Welfare Optimality." Review of Economic Studies, 66(1): 23-38.

Maskin, Eric, and Jean Tirole. 1999. "Unforeseen Contingencies and Incomplete Contracts." Review of Economic Studies, 66(1): 83-114.
Moore, John, and Rafael Repullo. 1988. "Subgame Perfect Implementation." Econometrica, 56(5): 1191-1220.

Watson, Joel. 2007. "Contract, Mechanism Design, and Technological Detail." Econometrica, 75(1): 55-82.

Whinston, Michael D. 2003. "On the Transaction Cost Determinants of Vertical Integration." Journal of Law, Economics, and Organization, 19(1): 1-23.

Williamson, Oliver E. 1975. Markets and Hierarchies: Analysis and Antitrust Implications. New York: Free Press.

Williamson, Oliver E. 1985. Economic Institutions of Capitalism. New York: Free Press. 